\title{
MOTYWY OCZU, ŚLEPOTY I ŚWIATŁA W PÓŹNEJ TWÓRCZOŚCI CZESŁAWA MIŁOSZA
}

Percepcja wzrokowa i towarzyszące jej procesy poznawcze to niezwykle ważna sfera doświadczeń - przestrzeń utrwalonych scenariuszy zachowań i dużej aktywności interpretacyjnej towarzyszącej różnym bodźcom oraz tekstom kultury. Jest to dziedzina, w której biologiczna natura człowieka - istoty posiadającej zmysł wzroku i wykorzystującej go na wielką skalę - poddawana jest regulacjom kulturowym pod wpływem praktyk społecznych i na skutek rozwoju różnych technik wizualnych. O doniosłości tej sfery świadczy utrwalenie przekonań o wzrokowej naturze poznania w takich fundamentalnych dla wszelkich wypowiedzi i dzieł sztuki pojęciach, jak punkt widzenia i perspektywa; dowodzi też tego obfitość metafor językowych i poetyckich sposobów obrazowania opartych na domenie wzroku' ${ }^{1}$. Motywy oczu, widzenia, oglądania, spoglądania na siebie i innych, oglądania się za siebie, wyglądu, wizualizacji, obrazu i obrazowania, odbicia i lustra - a także ich przeciwieństwa: ślepota, przeoczenie, tworzenie fałszywych wizerunków i pozornych odbić oraz powstawanie mylnych wyobrażeń - pojawiają się w mitach i baśniach, stanowią źródło wielu wątków fabularnych rozwijanych w utworach literackich i rozmaitych tekstach kultury.

Spośród licznych metafor językowych utrwalonych w polszczyźnie przywołajmy tu: „mieć na coś oko” (uważać na coś), ,przeoczyć coś” (nie zauważyć czegoś), ,patrzeć na coś krzywo” (odnosić się do czegoś niechętnie), „Zapatrywania” (poglądy na coś), „mieć coś na względzie” (brać coś pod uwagę), „studia zaoczne” (studia niestacjonarne, często: odbywane drogą korespondencyjną) itp. 
Przywołany tu konglomerat pojęć stanowi odwieczny przedmiot namysłu filozofów i stały obiekt zainteresowania antropologów, badaczy literatury i krytyków sztuki, w tym również teoretyków nowych sztuk wizualnych, jak fotografia czy film. W tej sytuacji trudno byłoby tu podać rozsądnie dobrany, a zarazem reprezentatywny zestaw opracowań tej dziedziny, bo ich liczba jest ogromna, a dobór tematu i kierunek analiz zależy od rodzaju dyscypliny naukowej, światopoglądu badacza lub założeń estetycznych stanowiących fundament danego nurtu artystycznego. Wspomnę tylko, że próbę zarysowania interesującego nas pola pojęciowego oraz garść refleksji nad poszczególnymi jego elementami składowymi przynosi m.in. wydany ostatnio tom zbiorowy pt. Vision and Cognition ${ }^{2}$.

Spójrzmy na tę bogatą dziedzinę pojęciową, na pewne wybrane jej fragmenty, z perspektywy (czy z punktu widzenia, przez pryzmat ${ }^{3}$ ) doświadczeń i przemyśleń jednego człowieka: wybitnego poety Czesława Miłosza. Przedmiotem oglądu będzie tu późny okres jego twórczości, utrwalony w tomie Druga przestrzeń (2002) i w wydanym pośmiertnie zbiorze Wiersze ostatnie (2006), którego zawartość i układ były pełnym pietyzmu dziełem edytora ${ }^{4}$. To okres, gdy 90-letni Miłosz uświadamia sobie utratę ostrości widzenia - tak ważnego dla kontaktu człowieka ze światem. To przykre doświadczenie - przykre szczególnie dla człowieka o takiej skali wrażliwości zmysłowej, jaką przez całe życie ujawniał Miłosz - skłania go do istotnych przemyśleń i przewartościowań.

W jednym $\mathrm{z}$ wierszy $\mathrm{z}$ tego okresu sędziwy poeta zwraca się do swoich oczu w sposób pełen szacunku, a zarazem poufały, traktując je jako autonomiczne byty. Forma tego zwrotu przywodzi na myśl apostrofę z fraszki Jana Kochanowskiego Na zdrowie, a samo potraktowanie oczu jako osobnej istoty jest wyrazem świadomości zapośred-

\footnotetext{
2 Vision and Cognition / Взгляд и познание, ed. by Teresa Dobrzyńska and Raya Kuncheva, Sofia 2011.

3 Te kategorie, jak też użyte w tym akapicie wyrażenia ,spójrzmy, na”, ,przedmiot oglądu", to oczywiście konkretne realizacje metafory pojęciowej WIDZIEĆ TO WIEDZIEĆ, modelującej poznanie.

4 Por. Czesław Miłosz, Druga przestrzeń, Kraków 2002 oraz tegoż, Wiersze ostatnie, zebrała, przepisała i datowanie ustaliła Agnieszka Kosińska, Kraków 2006.
} 
niczenia obrazu świata przez poszczególne zmysły. Pośrednictwa tego nie dostrzega człowiek młody, objawia się ono z całym dramatyzmem dopiero wtedy, gdy narządy zmysłów przestają być sprawne.

Oto rozmowa z oczami z wiersza Miłosza:

\section{OCZY}

Szanowne moje oczy, nie najlepiej z wami.

Dostaję od was rysunek nieostry,

A jeżeli kolor, to przymglony.

A byłyście wy sforą królewskich ogarów,

Z którymi wyruszałem niegdyś o poranku.

Chwytliwe moje oczy, dużoście widziały

Krajów i miast, wysp i oceanów.

Razem witaliśmy ogromne wschody słońca,

Kiedy szeroki oddech przyzywał do biegu

Po ścieżkach, na których podsychała rosa.

Teraz coście widziały, schowane jest we mnie

I przemienione w pamięć albo sny.

Oddalam się powoli od jarmarku świata

I zauważam w sobie jakby niechęć

Do małpowatych strojów, wrzasków, bicia w bębny.

Co za ulga. Sam na sam, z moim rozmyślaniem

O zasadniczym podobieństwie ludzi

I drobnym ziarnie ich niepodobieństwa.

Bez oczu, zapatrzony w jeden jasny punkt,

Który rozszerza się i mnie ogarnia.

22 VII 2001

[wiersz z tomu Druga przestrzeń]

Rola oczu we wcześniejszych okresach życia poety ukazana jest w tym utworze poprzez odwołania do trzech sfer doświadczeń. Po pierwsze są to doświadczenia młodego myśliwego, który ze sforą ogarów wychodzi o świcie na polowanie; następnie - to doświadczenia człowieka podróżującego po wielu kontynentach i doznającego wielu wrażeń; wreszcie - doświadczenia człowieka sprawnego fizycznie, 
uprawiającego jogging o wschodzie słońca, gdy nie obeschła jeszcze poranna rosa. W tych trzech sytuacjach oczy wykazują zdolność sprawnego dokonywania obserwacji i dostarczania przeżyć - także wrażeń estetycznych.

Wszystkie te sytuacje znajdują oparcie w doświadczeniach osobistych Miłosza, wyniesionych z różnych czasów i miejsc - od przedwojennych polskich Kresów po Amerykę, ale były to sytuacje typowe dla stylu życia określonych środowisk, więc są wpisane w pewne okoliczności kulturowe. Polowanie z ogarami ewokuje wspomnienie polskiej obyczajowości ziemiańskiej - wypraw myśliwskich młodego panicza, które były udziałem Miłosza w czasach jego młodości spędzonej na Litwie , a które niewiele - pewnie tylko skalą - różniły się od polowań z chartami, opisanych przez Mickiewicza w Panu Tadeuszu, lub polowania utrwalonego w Popiołach Żeromskiego w słynnym zdaniu rozpoczynającym tę powieść: „Ogary poszły w las”.

Z kolei sytuacja wędrowca to doświadczenie wielu ludzi współczesnych Miłoszowi związane z przemieszczaniem się z kraju do kraju, z kontynentu na kontynent; to los powojennych emigrantów (także tych wcześniejszych, ale oni podróżowali z mniejszą intensywnościa); to również los podróżników i turystów, korzystających z możliwości poznawania świata. I wreszcie - bieganie o poranku to rozpowszechniona w USA, a następnie w wielu krajach $\mathrm{z}$ kręgu cywilizacji euroamerykańskiej, forma uprawiania sportu: jogging - utrwalony m.in. w filmie Forest Gump. Miłosz przedstawia ten rodzaj aktywności fizycznej w postaci wzbogaconej o wymiar duchowy: nie jest to po prostu poranny trucht, lecz bieg uzasadniony chęcią kontemplowania "ogromnych wschodów słońca" - gdy nic nie przesłania horyzontu, a biegnący człowiek doznaje radości bezpośredniego kontaktu z przyroda, poruszając się ,po ścieżkach, na których podsychała rosa”.

Bogactwo wrażeń pozyskanych dzięki oczom zostało przetworzone poznawczo i utrwalone w pamięci poety. Teraz te doznania powracają w jego snach (rozumianych dosłownie lub mających charakter ma-

5 Wspomina o tym m.in. w wierszu Jak można zapomnieć, por. Czesław Miłosz, Wiersze, t. 2, Kraków-Wrocław 1984. Wymienia tam z imienia wiele psów, które towarzyszyły mu w polowaniach i włóczęgach. 
rzeń na jawie czy - jak określił to Shakespeare - stając „przed oczami duszy" ${ }^{\prime}$ ). Oczy pozyskujące wrażenia okazały się równie skuteczne w poszukiwaniach, jak rozbiegane na wszystkie strony i węszące za zwierzyną psy myśliwskie. Miały szansę obserwować różnorodność świata - jak podróżnicy wędrujący po wielu krajach. Mogły też doznawać zachwytu, kontemplując wschody słońca, a więc patrząc na to codzienne zjawisko kosmiczne, które oznacza powrót jasności, a którego oglądanie dane jest niewielu mieszkańcom miast, uwięzionych w ciasno zabudowanej przestrzeni.

Zapamiętajmy ten związek oczu z jasnością, światłem i słońcem. Jest on znamienny dla toku myślenia Miłosza i znajduje wyraz w innych jego wierszach.

Opisane własności wzroku młodego (czy przynajmniej dojrzałego) człowieka: sprawność jego oczu chwytających bogactwo wrażeń, zaciekawionych światem, pełnych radości życia i urzeczonych pięknem zjawisk - przedstawione są w wierszu jako stan przemijający, dobro utracone. Wraz z nadejściem starości zanika zdolność wyraźnego postrzegania, oczy przekazują obraz zatarty, o rozmytych barwach: „Dostaję od was rysunek nieostry, / A jeżeli kolor, to przymglony”. Z tymi objawami stopniowej utraty wzroku łączą się znamienne refleksje i przewartościowania. Sędziwy poeta docenia z jednej strony wartość utrwalonych w pamięci obrazów, z drugiej - doznaje ulgi, że nie musi już pewnych rzeczy oglądać, nie musi uczestniczyć we wrzaskliwym ,jarmarku świata”. Pozbawiony zdolności dostrzegania obrazów, w paradoksalny sposób zachowuje zdolność patrzenia: „bez oczu, zapatrzony”. Jego „zapatrzenie” ma szczególny charakter: jest to forma koncentracji władz poznawczych na jednym - jasnym - punkcie i poczucie kontaktu z wszechogarniającym światłem.

Zawarty w stwierdzeniu „bez oczu, zapatrzony” paradoks widzącego ślepca ma w kulturze europejskiej pradawne antecedencje i wiąże

${ }^{6}$ Por. ,HAMLET: My father! - methinks I see my father. / - HORATIO: O where, my lord? I- HAMLET: In my mind's eye, Horatio” - William Shakespeare, Hamlet, I, 2. 
się z utożsamieniem nabywania wiedzy z postrzeganiem wzrokowym. Metafora pojęciowa WIDZIEĆ TO WIEDZIEĆ znajduje rozwinięcie w pojmowaniu wiedzy w kategoriach światła, co tłumaczy sposób konceptualizacji nauki w kategoriach oświecenia umysłu. Rozumienie jako „widzenie w sposób jasny” staje się - na prawach projekcji pojęciowej - swego rodzaju widzeniem, różnym jednak od zwykłego postrzegania wzrokowego, które ogranicza się do rozpoznawania rzeczy oświetlonych światłem fizykalnym. Zwykły a zarazem powierzchowny ogląd wzrokowy, skupiony na pozorach i często prowadzący do błędów poznawczych, przeciwstawiony tu został oglądowi mentalnemu - dogłębnemu, przenikającemu naturę rzeczy i docierającemu do prawdy, a więc pozwalającemu widzieć jasno.

Od najdawniejszych czasów widzenie jako rozumienie bywało rozszerzane na zdolność przenikania tajemnic, odgadywania przyszłości - jasnowidzenie. Dla takiego oglądu oczy są niepotrzebne, stanowią wręcz przeszkodę. Tego rodzaju przeciwstawienia leżą u podstaw idei niewidomego, a zarazem jasnowidzącego mędrca. Topos ten znalazł zastosowanie w Królu Edypie Sofoklesa w postaci wieszczka Tejrezjasza. Również motyw oślepiającego się Edypa potwierdza istnienie takiej konfiguracji pojęciowej i rozróżniania dwu rodzajów patrzenia.

Analizując archaiczne sensy tragedii Sofoklesa, Sergiusz Awierincew rozważa utrwalony w archaicznym systemie pojęciowym i zakorzeniony $w$ języku starogreckim związek widzenia i wiedzy, ale zastrzega równocześnie, że „wzrok skierowany na zewnątrz niesie wiedzę zewnętrzna, zwróconą na powierzchnię rzeczy"'. Rozwijając ten kierunek myślenia, kultura grecka stworzyła opozycję widzenia (optycznego) pozorów i (mentalnego) widzenia rzeczy istotnych, ukrytego sensu:

W kulturze greckiej istnieje [...] przeciwważne pojmowanie naoczności jako pustej złudy [...]. W tym rozumieniu mędrzec, to znaczy demaskujący to, co niewidoczne, kontemplator istoty, powinien być ślepy. Ślepi byli wieszczy Tyrezjasz, wieszczy Homer i wieszczy Demodok. O Tyre-

\footnotetext{
7 Zob. Sergiusz Awierincew, W poszukiwaniu symboliki mitu o Edypie, w: tegoż, Na skrzyżowaniu tradycji (szkice o literaturze $i$ kulturze wczesnobizantyjskiej), przeł. i opatrzyła wstępem oraz notami bibliogr. Danuta Ulicka, Warszawa 1988, s. 166.
} 
zjaszu wiadomo przy tym, że utracił wzrok równocześnie z uzyskaniem daru prorokowania, o Demodoku zaś Homer mówi, że oślepiła go Muza, co też chętnie odnoszono do samego Homera. Symbolikę tę interesująco uogólnia potem filozofia grecka. [...] Szczególnie barwna jest znana opowieść o Demokrycie, który miał wyłupić sobie oczy, by jaśniej widzieć niewidzialne. Plutarch, nieufny wobec legendy, przekazuje ją w następujący sposób: „Toteż wprawdzie to, co powiadają o Demokrycie, jest nieprawdă, mianowicie, że dobrowolnie odebrał sobie wzrok [...] - a to, ażeby oczy nie zakłócały spokoju myśli, wywołując ją ustawicznie na zewnątrz, zamiast dać jej spokojnie przebywać w domu i zajmować się sprawami duchowymi ${ }^{8}$.

Rozpoznanie dwu rodzajów widzenia prowadzi do ironicznej konfrontacji widzącego, ale zaślepionego pozorami Edypa i ślepego, ale dostrzegającego głęboki sens zdarzeń Tejrezjasza (Tyrezjasza). Widzenie pozorów zostaje w swej funkcji poznawczej skompromitowane. Edyp wykłuwa sobie oczy, bo zawiodły go podsuwając zwodnicze obrazy. Rezygnuje z takiego ułomnego widzenia, bo chce przejrzeć naprawdę...

Wróćmy teraz do sytuacji opisanej w wierszu Miłosza. Sędziwy poeta traci wzrok, a równocześnie jest „zapatrzony w jeden jasny punkt” - zapatrzony oczami duszy, wewnętrznymi władzami poznania. To te władze mentalne umożliwiają mu m.in. rozmyślania „O zasadniczym podobieństwie ludzi / I drobnym ziarnie ich niepodobieństwa”. Podobnie jak to się stało $\mathrm{z}$ widzeniem, rozszczepieniu znaczeniowemu podlega tu sens jasności i światła. Nie są to już wyłącznie zjawiska natury fizycznej, lecz jakości duchowe, które przyciagają człowieka ze względu na swój szczególny walor: bohater wiersza jest „zapatrzony w jeden jasny punkt", nie może się od niego oderwać.

Pojęcie jasności odnoszone bywa w kulturze do sfery poznania wyraźnego i niebudzącego wątpliwości - por. zwroty: „mam jasne

8 Tamże, s. 167-168. Cytat z Plutarcha - zob. tegoż De curios, 12 p. 521 d. (Plutarch, O wścibstwie, w: tegoż, Moralia). 
wyobrażenie o czymś”, „ta sprawa pozostaje dla mnie niejasna”, „objaśnij mi to" itp.). Podobne sensy poznawcze wyrażane bywają przez antonimy jasności - ciemność, mrok - por. „to thumaczenie zaciemnia sprawe”, „człowiek ciemny” (niewykształcony), ,dyktatura ciemniaków”, „mroki Średniowiecza” itp. Jasność i ciemność są też nośnikami sensów symbolicznych dotyczących sfery moralnej. To symbolika archetypowa, obecna także w twórczości Miłosza. W jego wierszu Człowiek wielopiętrowy ${ }^{9}$ jasność (poranka) i ciemność występują w połączeniu z symboliką przestrzenną ,„góra”/,dół” i mają analogiczne znaczenia:

Idzie człowiek wielopiętrowy,

w górnych piętrach rześkość poranka,

a tam nisko

ciemne pokoje,

do których strach wchodzić.

Nie o te sensy jasności - jasności poznawczej czy jasności-dobra chodzi w wierszu Oczy. Choć poezja Miłosza nie jest poezją konfesyjną, dającą się zamknąć w granicach tradycyjnych wyznań, i choć sędziwy poeta bez przemilczeń i w sposób wstrząsający przedstawia w swych ostatnich utworach degradację sił fizycznych i niedolę starości, stwierdzając z gorzką ironią: „Co na to niebieskie moce? / Przechadzają się, patrzą ${ }^{10}$, to jednak w licznych jego późnych tekstach daje się odczuć wielkie pragnienie transcendencji - kontaktu z Boską Opatrznością, którą w dzieciństwie odczuwał jako „Obecność” i której właściwie do końca nie był zdolny utożsamić z jakąś kanoniczną koncepcją religijną. Tak więc, z jednej strony, poeta postrzega życie jako „obrót sezonów, zstępowanie w ziemię" raz Raju z niebem, „na którym słońce znaczy miłość”12.

Właśnie ta słoneczna aura, światło poranka, emanacja jasności, wyrażają stany duchowe towarzyszące zbliżeniu się do mocy trans-

$9 \quad \mathrm{Z}$ tomu Druga przestrzeń, z którego pochodzi wiersz Oczy.

10 Zob. wiersz Degradacja z tomu Druga przestrzeń.

11 Tamże.

12 Zob. wiersz „Ja” z tomu Druga przestrzeń. 
cendentnych ${ }^{13}$. W analizowanym wierszu jest to ,jasny punkt”, który rozszerza się i ogarnia utrapionego starego człowieka. Jasność ta jest dostrzegalna mimo utraty ostrości wzroku, dotyczy wewnętrznego odczucia światła i stanu ducha.

Jako analogiczne fakty utrwalone w kulturze można tu przywołać doznania przedśmiertne związane z wizją światłości. Doznania takie opisał Lew Tołstoj w opowiadaniu Śmierć Iwana Iljicza. U kresu swego trudnego żegnania się ze światem bohater tytułowy tego opowiadania „zamiast śmierci” dostrzega jaśniejące światło. Obraz światłości w wierszu Miłosza przypomina też opisy objawiania się jasności w doznaniach ludzi umierających - doznaniach odtworzonych po odzyskaniu świadomości przez tych, którym dane było przeżyć „,̇̇ycie po życiu".

Nie trzeba jednak w ten sposób konkretyzować doznań opisanych przez Miłosza. W kategoriach archetypowych wyraża on stan ostatecznego zjednoczenia z tym, co dobre, co jest emanacją boskiej miłości. Tracąc wzrok fizyczny, stary, udręczony niemocą człowiek odzyskał zdolność odczucia tego, co jest najwyższym dobrem i miłością.

Zjednoczenie $\mathrm{z}$ jasnością nie jest tu równoznaczne $\mathrm{z}$ pełnym rezygnacji przyzwoleniem na nieuchronną śmierć - wobec utraty władz cielesnych i niemożności radowania się życiem ${ }^{14}$. Jasność objawia się tu jako siła przygarniająca człowieka, wybawiająca go od udręki, wyzwalająca. Kontakt z nią ma wyraźne implikacje religijne: to swego rodzaju wniebowstapienie. Towarzyszy temu spokój wewnętrzny i poczucie dotarcia do prawdy. W wierszu Późna dojrzatość (z tego samego tomiku) poeta pisze:

Nieprędko, bo dopiero pod dziewięćdziesiątkę, otworzyły się drzwi we mnie i wszedłem w klarowność poranka.

13 Omawiając symbolikę światła, Władysław Kopaliński wylicza m.in. takie jego symboliczne znaczenia: wieczność, duch, bezcielesność, niematerialność, życie, szczęście, chwała, Bóg, Chrystus, niebo, świętość, objawienie - por. W. Kopaliński, hasło: Światło, w: Słownik symboli, Warszawa 1990.

14 Taki sens zakończenia wiersza Eyes sugeruje Ira Sadoff w swym omówieniu treści tomu Second Space, nie odnajdując w nim wątków religijnych, co jest w moim pojęciu nieuzasadnione - por. I. Sadoff, Czeslaw Milosz and the Late Style, „The American Poetry Review”, March/ April 2007, vol. 36, issue 2, s. 47. 
„Otwarcie drzwi” do jakichś wewnętrznych przestrzeni duchowych pozwalających odzyskać pogodę ducha, to stan równoznaczny z otwarciem oczu na niepojęte dotąd wymiary bytu. Wracamy tu do figury ślepego mędrca - do paradoksu odzyskiwania ostrości widzenia wraz z utratą wzroku fizycznego. Poddanie się emanacji światła oznacza zjednoczenie z mocami transcendentnymi, dlatego też towarzyszy temu spokój wewnętrzny i radość.

W obrazie ,jednego jasnego punktu”, który rozszerza się i ogarnia starego ślepnącego człowieka, mamy zawarty jeszcze jeden paradoks: nieskończenie pojemnego punktu - punktu, a więc elementu, który, jak uczy geometria, nie ma przecież wymiarów. Co prawda, współczesna kosmologia uznaje teorię punktowego początku wszechświata i stopniowej ekspansji materii, ale obrazowanie Miłosza nie ma tak wyraźnych odniesień do zjawisk kosmicznych. Jest ono raczej osadzone w tradycji takich wyobrażeń sacrum, jakie znalazły wyraz w serii oksymoronów i paradoksów w kolędzie Bóg się rodzi [Pieśń o Narodzeniu Pańskim] Franciszka Karpińskiego, w której „ogień krzepnie, blask ciemnieje, / ma granice Nieskończony". Podobne połączenie ślepoty fizycznej z innego rodzaju widzeniem - „wzrokiem nowym”, i podobne utożsamienie Boga ze Słońcem znajdziemy w jednym $\mathrm{z}$ utworów z tomu Wiersze ostatnie ${ }^{15}$. Co znamienne, utwór ten jest pisany z perspektywy wspólnoty ludzkiej. Rozterki udręczonego ,ja" zostają przezwyciężone i człowiek pojedynczy wtapia się w zbiorowość, której dane jest przeżyć stan iluminacji przynoszący wyzwolenie spod władzy czasu i przemijania, a równocześnie umożliwiający osiagnięcie pełni samowiedzy:

Obróceni twarzami ku Niemu, otrzymaliśmy wzrok nowy, zdolny patrzeć w Słońce.

Czyż nie było zawsze naszym największym pragnieniem żyć i na wieki zamieszkiwać w jasności?

\footnotetext{
15 Zob. *** ([,,Obróceni twarzami ku Niemu...”]), w: Czesław Miłosz, Wiersze ostatnie, dz. cyt.
} 
Ślepi, kulawi, paralitycy, pokręceni

żyliśmy w wigorze lat odzyskiwanych.

Czas przeszły, czas teraźniejszy i czas przyszły

łączyły się w jeden niby-czas.

Co było, co jest i co będzie

ukazywały się niemożliwe do rozróżnienia.

Nareszcie rozumieliśmy nasze życie,

ze wszystkim, co się w nim nadziało.

Myśl o boskiej jasności przynosi nadzieję w trudnych latach późnej starości Miłosza. Jest to może bardziej pragnienie niż konstatacja; pragnienie zrodzone $\mathrm{z}$ udręki i wyrażane $\mathrm{w}$ chwilach przygnębienia, „na głębinach [...] depresji”, gdy poeta ,poznał świat bez nadziei, / A kolor jego szary, jak dzień odgrodzony chmurami od słońca"16. Poszukując źródeł nadziei, Miłosz zwraca się ku wielowiekowej tradycji myśli religijnej, rozwijanej w różnych środowiskach kulturowych. Woła językiem psalmów:

Królu Jasności podejmij mnie!

Dawco Miłosierdzia przepasz mnie!

Amonie, Zeusie, Jehowo włącz mnie w twoje chóry!

Upragniony kontakt z Transcendentnymi Mocami przedstawiony jest tu z gorzką świadomością żałosnej kondycji ludzkiej i w poczuciu wspólnoty opartej na podstawowych doświadczeniach egzystencjalnych. Dominującym motywem jest motyw światła - w jego archetypowych sensach symbolicznych, wykorzystywanych i rozbudowywanych przez wieki w liturgii i sztuce sakralnej ${ }^{17}$.

16 Por. wiersz $W$ depresji z tomu Wiersze ostatnie, dz. cyt.

17 Por. np. sztukę witraży w gotyku i symbole solarne w świątyniach chrześcijańskich tak intensywnie obecne w sztuce baroku, np. promieniste okno w absydzie Bazyliki św. Piotra na Watykanie. 
Symbolika świetlna pojawia się u Miłosza wielokrotnie. Najpiękniejsze chyba jej wysłowienie znajdziemy w pierwszych słowach wiersza-modlitwy Jasności promieniste:

Jasności promieniste,

Niebiańskie rosy czyste,

Pomagajcie każdemu

Ziemi doznającemu ${ }^{18}$.

Moce niebieskie, nazwane tu nowym imieniem - zwielokrotniającym ich blask, są mocami opiekuńczymi. Do nich kieruje się pełna ufności modlitwa tych, którzy, żyjąc na ziemi, doznają wszystkiego tego, co ziemskie. Nadzieja, że modlitwy będą wysłuchane, kryje się w strukturze samych obrazów metaforycznych: zarówno promienie słoneczne rozchodzące się od źródła światła, jak i rosy spadające z nieba spływają ku ziemi: ogarniają ziemię swym blaskiem i zraszają odświeżającymi kroplami wody.

\begin{abstract}
The subject of the examination here is a late period of Miłosz's literary output (volumes: „Druga przestrzeń” and „Wiersze ostatnie”). While discussing the motif of eyes, blindness and light the author brings up a general and serious problem of the poet's vision in his final poems: he uses this theme in existential and metaphysical contexts
\end{abstract}

Transl. Joanna Stolarek

$18 \mathrm{Z}$ tomu $T o$, Kraków 2000. 